\title{
PENGUATAN NILAI SOSIAL PADA PELATIHAN DASAR PENCAK SILAT BAGI SISWA SMA NEGERI 1 MODAYAG BOLAANG MONGONDOW TIMUR
}

\author{
Abdul Rasyid Umaternate, Awaluddin Hasrin \\ Universitas Negeri Manado, Indonesia \\ rasyidumaternate@unima.ac.id
}

\begin{abstract}
Silat is a martial art that has existed for a long time in the archipelago. Nowday silat has become a feature of our cultural identity. That is a cultural rdentity related to martial arts. Silat activities are not only interpreted as just sports as in general, but silat activities are also part of a learning process about existing social values. It is hoped that this activity will strengthen the students' understanding of SMA Negeri 1 Modayag Bolaang Mongondow Timur about the social values contained in pencak silat activities. The observations made show that in general the participants have internalized their own social values. Students at SMA Negeri 1 Modayag who take basic pencak silat training have implemented social values including discipline and being obedient in participating in the training carried out, especially on timeliness in following activities and rules or instructor instructions during training activities. In addition, the students also showed a cooperative attitude between the participants during the training.
\end{abstract}

Keywords: Pencak Silat, Social Values.

\begin{abstract}
Abstrak
Silat merupakan bela diri yang telah ada sejak dulu di Nusantara. Saat ini silat telah menjadi satu ciri dari identitas budaya kita. Yaitu sebuah identitas kebudayaan yang terkait dengan seni beladiri. Kegiatan silat tidak hanya dimaknai sekedar kegiatan olah raga seperti pada umumnya namun kegiatan bersilat juga merupakan bagian dari sebuah proses belajar tentang nilai-nilai sosial yang ada. Tujuan kegiatan ini diharapkan pemahaman para siswa di SMA Negeri 1 Modayag Bolaang Mongondow Timur tentang nilai-nilai sosial yang terkandung dalam kegiatan pencak silat mengalami penguatan. Dari pengamatan yang dilakukan menunjukan bahwa pada umumnya peserta telah menginternalisasikan nilai-nilai sosial pada dirinya masing-masing. Para siswa di SMA Negeri 1 Modayag yang mengikuti peltihan dasar pencak silat telah menerapkan nilai-nilai sosial meliputi disiplin dan taat dalam mengikuti pelatihan yang dilakasanakan, terutama pada ketepatan waktu dalam mengikuti kegiatan dan aturan atau intruksi instruktur selama keagiatan pelatihan. Selain itu para siswa juga menunjukkan sikap perilaku kerja sama antara para peserta selama pelaksaan pelatihan.
\end{abstract}

Kata Kunci: pencak silat, nilai sosial.

\begin{tabular}{l|l|l} 
Submitted: $2020-09-16$ & Revised: $2020-09-29$ & Accepted: 2020-09-30
\end{tabular}

\section{Pendahuluan}

Pencak silat adalah seni bela diri yang ada di Indonesia. Seni bela diri ini sejak lama telah dikenal di Nusantara bahkan hingga ke manca Negara seperti Filipina, Malaysia Singapura dan Brunei. Saat ini Silat telah menjadi salah satu ciri dari identitas budaya bangsa Indonesia. Sejak dahulu nenek moyang bangsa ini telah memiliki cara dalam pembelaan diri yang ditujukan untuk melindungi dan mempertahankan kehidupan nya atau kelompoknya dari tantangan alam (Gilang, 2007). Pada dasarnya kegiatan bela diri merupakan dari gerakan-gerakan binatang yang ada di alam sekitar kita. Nenek moyang kita mengamati gerakan-gerakan binatang kemudian mengadopsinya menjadi gerakan 
geraka dalam bela diri, seperti gerakan kera, harimau, ular atau burung. Selain gerakan binatang, perkembangan identitas silat sebagai warisan kebudayaan mengadopsi teknik teknik lainnya tidak hanya yang terdapat dari Nusantara, tetapi terjadi proses asimilasi dari teknik-teknik mancanegara lainnya seperti dari Negara Cina dan beladiri Eropa lainnya. Asal mula ilmu bela diri di nusantara ini kemungkinan juga berkembang dari keterampilan suku-suku asli Indonesia dalam berburu dan berperang dengan menggunakan parang, perisai, dan tombak dengan memanfaatkan benda-benda sekeliling (Alexander, 1972). Bela diri tersebut berfungsi sebagai pembelaan diri terutama serangan dari binatang buas dan serangan kelompok lain dalam memperebutkan bahan makanan.

Silat diperkirakan menyebar di kepulauan nusantara semenjak abad ke-7 masehi, akan tetapi asal mulanya belum dapat ditentukan secara pasti. Kerajaan- kerajaan besar, seperti Sriwijaya dan Majapahit disebutkan memiliki pendekar- pendekar besar yang menguasai ilmu bela diri dan dapat menghimpun prajurit-prajurit yang kemahirannya dalam pembelaan diri dapat diandalkan. Penelitian Donald F. Draeger membuktikan adanya seni bela diri bisa dilihat dari berbagai artefak senjata yang ditemukan dari masa Hindu-Budha serta pada pahatan relief-relief yang berisikan sikap-sikap kuda-kuda silat di candi Prambanan dan Borobudur. Masyarakat Indonesia kala itu memakai senjata dan seni beladiri silat adalah tak terpisahkan, bukan hanya dalam olah tubuh saja, melainkan juga pada hubungan spiritual yang terkait erat dengan kebudayaan Indonesia. (Draeger, 1992).

Selain itu, hubungan perdagangan dan kerjasama Indonesia dengan negara lain memberikan pengaruh ilmu bela diri dari Cina dan India dalam silat. Hal ini terjadi sejak awal kebudayaan Melayu telah mendapat pengaruh dari kebudayaan yang dibawa oleh pedagang maupun perantau dari India, Cina maupun Eropa, sehingga teknik silat nusantara sangat berkembang dan banyak dipengaruhi oleh berbagai Negara pendatang yang disesuaikan dengan kondisi masyarakat Indonesia pada masa itu. Dalam masyarakat majemuk di Indonesia, pembauran terjadi dalam kebuda yaan Indonesia, begitupun dengan perkembangan silat di Indonesia. Profil pencak silat di Indonesia dapat dikelompokkan ke dalam tiga bagian yaitu: 1) Pencak silat asli (original), ialah pencak silat yang berasal dari lokal dan masyarakat etnis di Indonesia. 2) Pencak silat bukan asli yang sebagian besar berasal dari Kung Fu, Karate dan Jujitsu. 3) Pencak silat campuran, ialah campuran antara pencak silat asli dan bukan asli (beladiri asing yang ingin bergabung dengan nama pencak silat sesuai peraturan AD dan ART IPSI) (Kumaidah, 2012)

Kini pencak silat telah merambah masuk dalam dunia pendidikan. Di berbagai sekolah dari tingkat SD sampai Perguruan Tinggi, Pencak Silat menjadi bagian dari kegiatan ekstra kurikuler yang banyak di gemari. Bahkan Pencak Silat telah menjadi salah satu cabang olahraga yang ditandingkan dalam berbagai kejuaraan baik tingkat nasional sampai tingkat dunia. Jika keempat aspek tersebut dapat dipadukan dalam diri pesilat, sudah barang tentu akan menjadi salah satu unsur perekat bangsa untuk bersatu dan mengangkat harkat, derajat, dan martabat bangsa Indonesia di mata dunia. Penelitian Wilson menghasilkan bahwa seni bela diri Indonesia bernama Pencak Silat merupakan sarana budidaya tubuh, wahana pengembangan spiritual, seni pertunjukan, dan olahraga internasional dan sejarahnya terkait erat dengan munculnya negara Indonesia. Silat dapat dijelaskan melalui ilmu pengetahuan, pedagogi Pencak Silat, kekuatan tubuh maupun 
warisan $\mathrm{n}$ enek moyang termasuk pengelolaan tradisi; dari mistis ke molekul; dan badan berdaulat dan praktis kekuasaan (Wilson, 2015).

Sasaran dalam kegiatan PKM ini adalah siswa yang mengikuti kegiatan ekstrakurikuler pelatihan dasar pencak silat di SMA Negeri 1 Modayag Bolaang Mongondow Timur Provinsi Sulawesi Utara. Dengan melihat beberapa persoalan prioritas yang telah diidentifikasi dan membutuhkan penyelesaian yaitu kurangnya minat siswa mempelajari seni pencak silat dan kurangnya nilai sosial dalam diri setiap peserta pencak silat. Dari kegiatan PKM ini diharapkan silat tidak hanya dimaknai sekedar kegiatan olah raga seperti pada umumnya namun kegiatan bersilat juga merupakan bagian dari sebuah proses belajar. Belajar adalah suatu proses yang kompleks dan terjadi pada diri setiap orang sepanjang hidupnya. Proses belajar itu terjadi karena adanya interaksi antara seseorang dengan lingkungannya. Oleh karena itu, belajar dapat terjadi di mana saja dan kapan saja. Salah satu tanda seseorang telah belajar adalah adanya perubahan tingkah laku pada diri seseorang tersebut yang mungkin disebabkan oleh terjadinya perubahan pada tingkat pengetahuan, keterampilan, atau sikapnya. Pembelajaran dalam silat membentuk karakter disiplin dan peningkatan fisik, maka setelah terjadinya proses belajar silat, kemampuan disiplin dan fisik dapat terlihat berkembang.

\section{Metode}

Untuk mencapai tujuan kegiatan ini, digunakan metode simulasi/ latihan, metode, ceramah dan diskusi. Metode simulasi/ latihan digunakan untuk memberi keterampilan dan pemahaman secara langsung tentang gerakan-gerakan dalam seni bela diri silat. Sementara metode ceramah dan diskusi digunakan untuk memberi pemahaman dan penguatan tentang nilai-nilai sosial yang terkandung dalam kegiatan pelatihan dasar pencak silat. Pada tahap pertama dilakukan dengan cara pembekalan atau praktek melalui kegiatan pelatihan dasar pencak silat yang dilaksanakan sesuai dengan waktu yang telah ditentukan. Tahap ini dilakukan dengan praktek langsung tentang jurus-jurus dasar dalam bela diri pencak silat yang dipandu oleh pelatihan serta instruktur yang berkompeten, Selanjutnya Pada tahap ceramah dan diskusi dijelaskan tentang; (1) Konsep dasar nilai sosial, (2) Jenis nilai sosial serta (3) Peran nilai sosial, hal ini penting dilakukan, karena dengan memberi pengetahuan dasar pencak silat melalui simulasi atau latihan serta nilai-nilai sosial yang terkandung dalam kegiatan pelatihan dasar pencak silat melalui metode ceramah dan diskusi dapat terinternalisasi dalam diri siswa yang mengikuti kegiatan ini.

\section{Hasil dan Pembahasan}

Pencak silat adalah hasil budaya manusia Indonesia untuk membela/ mempertahankan eksistensi (kemandirian) dan intengritasnya (manunggalnya) terhadap lingkungan hidup/ alam sekitarnya untuk mencapai keselarasan hidup guna meningkatkan iman dan taqwa kepada Tuhan Yang maha Esa (Lubis, 2000). Disini peranan pencak silat adalah sebagai prasarana dan sarana untuk membentuk manusia seutuhnya yang pancasilais, sehat, kuat, trampil trenginas, tangkas, tenang, sabar, bersifat kesatria, percaya kepada diri sendiri. Pencak silat mempunyai sifat dan ciri khususnya sebagai berikut : Kehususan pencak silat dalam gerak dan usaha (Weda, 2015). 


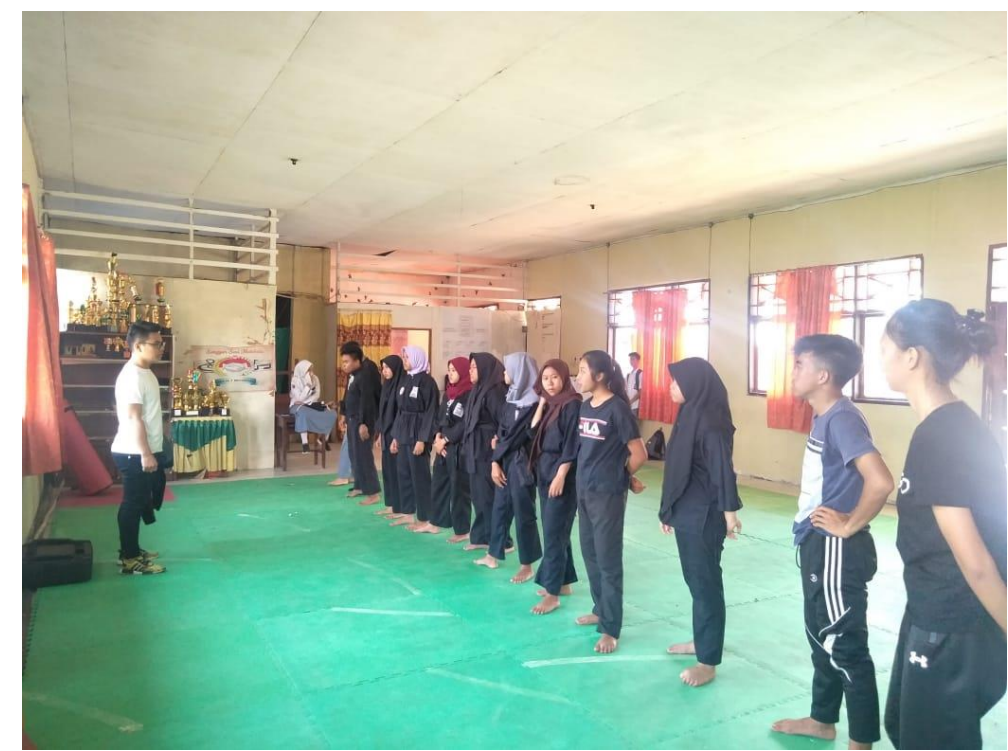

Gambar 1. Persiapan dan Cek Kesiapan Fisik

Pembentukan sikap pada pencak silat merupakan dasar dari pembentukan gerak yang meliputi sikap jasmaniah dan sikap rohaniah. Sikap jasmaniah adalah kesiapan fisik untuk melakukan gerakan-gerakan dengan kemahiran teknik yang baik. Sikap rohaniah adalah kesiapan mental dan pikiran untuk melakukan tujuan dengan waspada,siaga praktis dan efisien. Pada pembentukan sikap berdiri ada tiga sikap yaitu pertama sikap tegak yang meliputi sikap tegak satu,sikap tegak dua, sikap tegak tiga dan sikap tegak empat. Yang mana masing-masing sikap memiliki peranan yang berbeda. Namun secara keseluruhan pembentukan sikap tegak bertujuan untuk menanamkan nilai displin pada pesilat. Kedua adalah sikap salam dan sikap berdoa. Sikap ini dipergunakan untuk penghormatan dan pemusatan diri memohon keselamatan kepada Tuhan Yang Maha Esa. Dimana di dalamnya terdapat nilai kerohanian dan sikap saling menghormati serta toleransi. Ketiga sikap kangkang adalah sikap dasar langkah dan kuda-kuda. dimana d idalamnya pembentukan diri yang tanggap, tangkas dan kepercayaan diri.

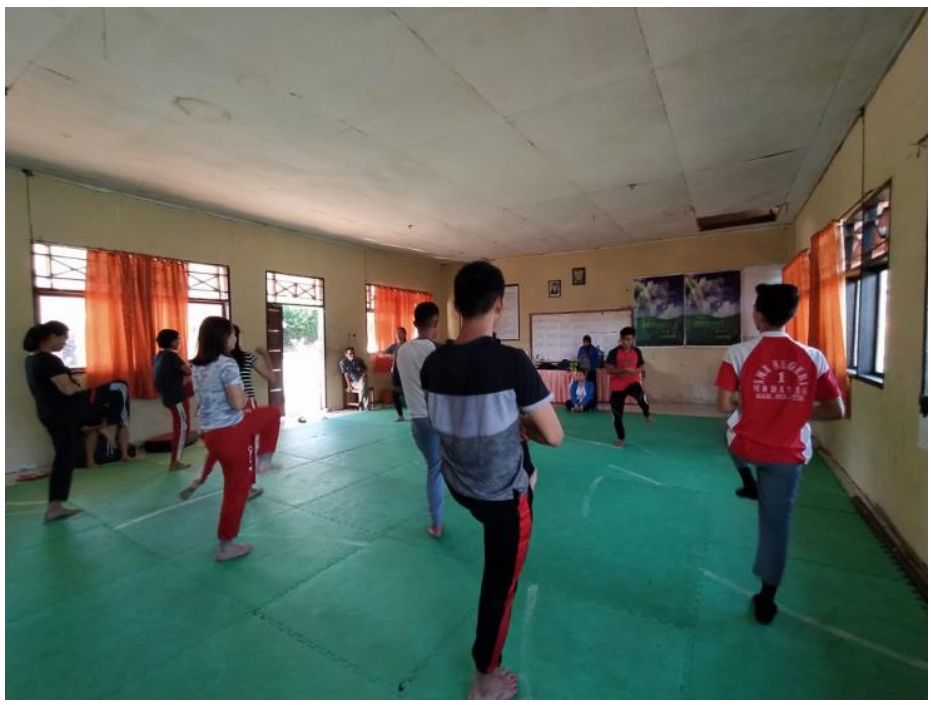

Gambar 2. Gerakan Dasar 
Pada pelatihan dasar pencak silat, para siswa dituntut untuk menginternalisasi nilai-nilai sosial yang terkandung dalam setiap gerakan yang ada. nilai disiplin dan taat dalam mengikuti pelatihan yang dilakasanakan, terutama pada ketepatan waktu dalam mengikuti kegiatan dan aturan atau intruksi instruktur selama keagiatan pelatihan. Selain itu para siswajuga menunjukkan sikap perilaku kerja sama antara para peserta selama pelaksaan pelatihan.

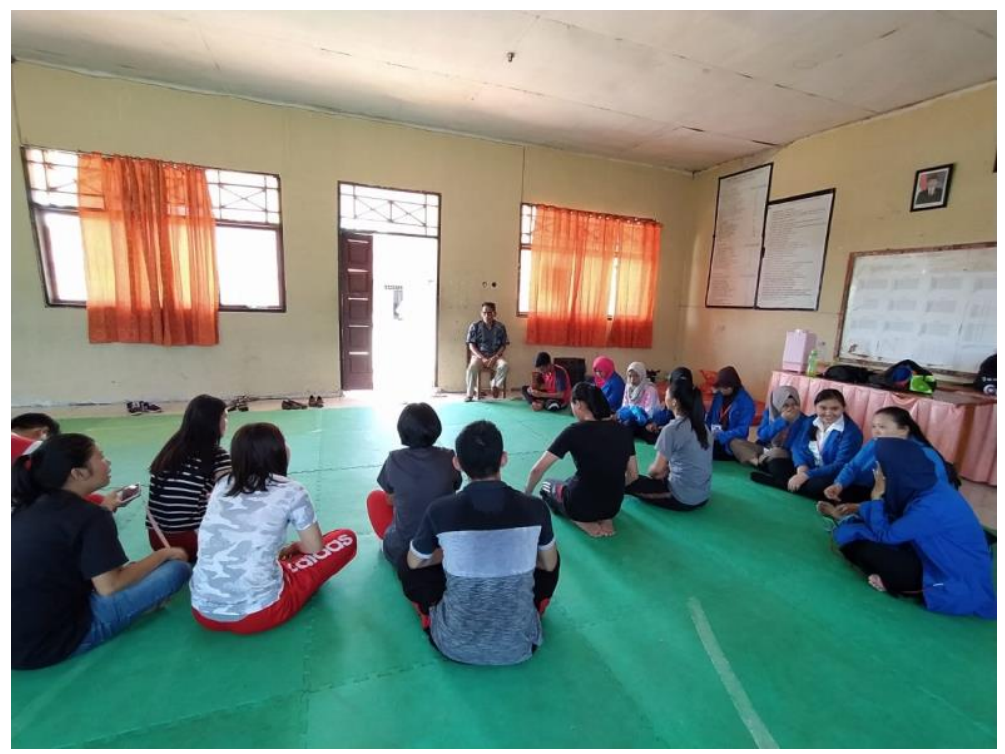

Gambar 3. Penguatan Nilai - Nilai Sosial Pada Pelatihan Pencak Silat

Setelah kegiatan pelatihan dilaksanakan dengan metode simulasi/ praktek dan metode ceramah, maka hasil yang di capai adalah sebagai berikut:

1. Setelah mengikuti pelatihan dasar pencak silat, maka pemahaman para siswa di SMA Negeri 1 Modayag Boltim tentang nilai-nilai sosial yang terkandung dalam kegiatan pencak silat mengalami penguatan. Dari pengamatan yang dilakukan menunjukan bahwa pada umumnya peserta telah menginternalisasikan nilai-nilai sosial pada dirinya masing-masing.

2. Para siswa di SMA Negeri 1 Modayag yang mengikuti peltihan dasar pencak silat telah menerapkan nilai-nilai sosial meliputi disiplin dan taat dalam mengikuti pelatihan yang dilakasanakan, terutama pada ketepatan waktu dalam mengikuti kegiatan dan aturan atau intruksi instruktur selama keagiatan pelatihan.

3. Selama mengikuti kegiatan pelatihan dasar pencak silat, para siswa menunjukkan sikap perilaku kerja sama antara para peserta selama pelaksaan pelatihan.

\section{Kesimpulan}

1. Setelah mengikuti pelatihan dasar pencak silat, maka pemahaman para siswa di SMA Negeri 1 Modayag Boltim tentang nilai-nilai sosial yang terkandung dalam kegiatan pencak silat mengalami penguatan. Dari pengamatan yang dilakukan menunjukan bahwa pada umumnya peserta telah menginternalisasikan nilai-nilai sosial pada dirinya masing-masing. 
2. Para siswa di SMA Negeri 1 Modayag yang mengikuti peltihan dasar pencak silat telah menerapkan nilai-nilai sosial meliputi disiplin dan taat dalam mengikuti pelatihan yang dilakasanakan, terutama pada ketepatan waktu dalam mengikuti kegiatan dan aturan atau intruksi instruktur selama keagiatan pelatihan.

3. Selama mengikuti kegiatan pelatihan dasar pencak silat, para siswa menunjukkan sikap perilaku kerja sama antara para peserta selama pelaksaan pelatihan.

\section{Daftar Pustaka}

Alexander, H. (1972). Pentjak-Silat: Indonesian Fighting Art. Tokyo: Kodansha.

Draeger, D. F. (1992). Weapons and fighting arts of Indonesia. Rutland, Vt : Charles E. Tuttle Co.

Gilang, M. (2007). Pendidikan Jasmani, Olahraga dan Kesehatan untuk SMA. Ganeca Exact.

Kumaidah, E. (2012). Penguatan Eksistensi Bangsa Melalui Seni Bela Diri Tradisional Pencak Silat. Humanika, 16(9), 1-9.

Lubis, J. (2000). Panduan Praktis Pencak Silat. Jakarta: Raja Grafindo.

Weda, M. N. (2015). Implementasi Nilai-Nilai Pembentukan Sikap Dalam Pencak Silat Terhadap Perilaku Mahasiswa Penjaskesrek UNP Kediri. Jurnal Sportif, 1(1), 100113.

Wilson, I. (2015). Martial Arts and the Body Politic in Indonesia. Cardiff University Press. 